\title{
International opportunities: searching for the meaning of student migration
}

\author{
Allan M. Findlay, Alexandra Stam, Dundee, Russell \\ King, Enric Ruiz-Gelices, Sussex
}

\section{Introduction}

Researchers interested in human mobility, particularly those investigating international migration, have been slow to appreciate the importance of international student migration. This article seeks to illustrate the importance of understanding student migration by drawing on qualitative aspects of an extensive survey of student mobility (KING et al. 2004a). In particular, we ask questions such as: What values underpin the meaning of international migration to the student population? How do students experience mobility and what are the main benefits that they associate with it? And what can researchers gain from mapping the meaning as well as the spatiality of student migration?

To answer these questions, we hear the voices of students as well as staff and what we call «mobility managers». Selection of these voices only occurred after the authors had already undertaken large-scale questionnaire surveys on the topic (KING \& RUIZ-GeLICES 2003; KING et al. 2004b). Thus in the academic arena, the qualitative contribution of the paper is nested within a multi-method approach to studying migration (FIndLAY \& Li 1999). The research is also set in the policy context of the United Kingdom. Here the key concerns are the impact of recent outward student mobility trends for the British economy, and whether the United Kingdom's somewhat limited «mobility culture» (compared to other European countries) disadvantages potential migrant students by biasing their outlook on «international» matters in general, and «Europe» in particular (KING et al. 2004b).

\section{International student mobility: reviewing what is known}

Most textbooks on human migration say absolutely nothing about students, a remarkable oversight given students' propensity to be spatially mobile and the justifiable claim of the OECD that any "panorama of [contemporary migration] flows cannot ignore international student mobility» (SOPEMI 2001: 93). In the United Kingdom, as in some other countries, many more migrants enter each year on student visas than under any other legal visa category. When attention is paid in the literature to students, the key issues referred to are usually those of «brain drain» and the international «business» of studying abroad, particularly within the Asia-Pacific region (CASTLES \& MiLLER 1998: 157; SKELdON 1997: 108-112; KUPTSCH 2005).

Some have argued recently that student mobility is a particular type of migration (MuRPHY-LEJEUNE 2003; King \& Ruiz-Gelices 2003), paralleled by other distinctive group mobilities such as the international migration of the elderly (KING, Warnes \& Williams 1998). For some, student mobility arises from personal choices, such as the wish to enhance foreign language skills, career prospects, cultural experience and personal development (WEST et al. 2001). For others, student mobility is influenced by background factors, such as the socio-economic environment of the student (SCHNitZER \& ZEMPEL-Gino 2002) or previous mobility experiences (MurPhy-LeJeUne 2003; Teichler \& JAHR 2001). Others have found it harder to define the drivers of student migration (COMMISSION OF THE European Communities 2000; Teichler \& Maiworm 1997: 39-40) attesting the need for more research in order to achieve a better understanding of the forces underpinning student mobility. It is not our intention to offer an extensive review of the literature here since we have done this elsewhere (Ruiz-Gelices et al. 2003). Instead we focus specifically on the conceptual geography of international student migration.

Within geography, the small number of studies of student mobility can be grouped into three categories (KING \& Ruiz-Gelices 2003). A first perspective views students as a subset of skilled migration (FIndLAY 2002); more precisely students can be seen as a potential flow of future qualified workers, either during a course of study or, more likely, through subsequent recruitment (SOPEMI 2001: 93). Second, increased student mobility has been conceptualised as a product of globalisation, both generally (increased global flows of goods, capital, people, ideas) and of higher education (Altbach \& Teichler 2001; KwIEck 2001). A subset of this approach relates to «Europeanisation» and the role of mobile, multilingual students/graduates as agents of European integration - the new professionals or, as FAVELL calls them, «Eurostars» (FAVELL 2004; KING 2003). In this approach, students wish, or are persuaded, to be mobile because they will be more internationally competitive in seeking employment, they will develop linguistic skills and intercultural awareness, and perhaps see themselves as more «European» or «cosmopolitan» and less «nationalistic» in their identities. A third interpretative strand places international student mobility within «youth 
mobility cultures». Here, «going abroad» (to study, travel or do voluntary work) is motivated less by traditional economic migration factors (to find a job, better income) and more by experiential goals. At a higher conceptual level this fits with the notion of the «doit-yourself» biography of the young, post-modern individual (BeCK \& BeCK-GeRNSHEIM 2002).

Key purposes of this paper therefore include listening to student voices to test the validity of the three-fold typology described above, and to ask whether other readings of student mobility are needed. Analysis of the transcripts of our student interviews allows us to ask several important questions. These include: Is student migration something that can be understood only in the context of the moment of movement or is it more deeply embedded in the social framing of the life course? And is there any evidence to justify treating student migration as different from other forms of mobility? That is to ask, is student mobility generically different from other mobilities or just a sub-set of what the academic literature has already made known?

\section{Setting the context}

Student migration is defined in the literature in many different ways (LANZENDORF \& TEICHLER 2002). Here we define a student migrant as someone who leaves his or her country of usual residence to enrol at a higher education institution, or to pursue some other academically or vocationally recognised activities abroad, for at least a term (around three months) within their overall programme of study in higher education.

This definition hides many particularities. Mobility can differ in duration, occur at different times during a student's degree and involve either large inter-institutionally organised mobility schemes of study or work abroad or be initiated by the student's department or on a more individual basis. It can include academic study, independent research, teaching, work experience (industrial placement, internship, clinical practice) or more unstructured «life experiences» not necessarily connected to any higher education qualification. The best-known European student mobility scheme is the Socrates-Erasmus exchange programme, but there are many other schemes operating at different levels and serving a diversity of purposes.

Secondary data show that student mobility, in global terms, has grown considerably over the past decade from 1.6 million tertiary-level students studying abroad in 1996 to 1.8 million in 2000 and a projected 2.8 million by 2010 (BRUSH \& BARTY 1998). The United
Kingdom has experienced growing upward outward student mobility, but at a slower pace than most other advanced countries, and a very rapid increase in inward mobility of foreign students. International students made up 11 per cent of the student population of the United Kingdom in 2002-3 (HIGHER Education Statistics Agency, HESA, 2004), but as Figure 1 shows there is a major imbalance between the numbers of Erasmus-sponsored international students entering the United Kingdom and the number of UK students seeking to study or work abroad under this scheme.

Student mobility within the Erasmus scheme does not fit neatly within the global trends in student mobility described above. In most countries (and especially Germany, France, Italy and Spain) Erasmus exchanges remain very popular. In some others, especially in the United Kingdom, there has been a very marked decline in outward student mobility to other EU countries since the late 1990s. This downward trend in the United Kingdom was a major catalyst behind government funding for the research reported in this paper.

\section{Methodology}

Our research involved a large representative questionnaire survey of 1200 students, as well as interviews with students, academics and mobility managers. Details of how the survey was designed to represent different higher education institutions across the United Kingdom, different types of courses, and students from diverse backgrounds, have been reported elsewhere (KING et al. 2004b) and are not repeated here. Our research focused especially on the experience of finalyear students who had been abroad, whom we define as «mobile», but the survey also involved first-year as well as non-mobile students in order to make comparisons of the perceived benefits of and barriers to international migration.

We conducted face-to-face interviews with 140 students spread across 10 institutions. Focus-groups conducted with about five students in each university, raised the total number of voices to 180 . Whereas the interviews were balanced between 67 mobile and 73 non-mobile students, focus groups were intentionally biased to capture the shared and divergent views of mobile students. Interviews were also conducted with a total of 46 academic, managerial and administrative personnel; the objective here was to find out how mobility is perceived, organised and promoted at the institutional level. The voices of all students were anonymised, but an indication of their course and migration destination is given after each quote as part of the 


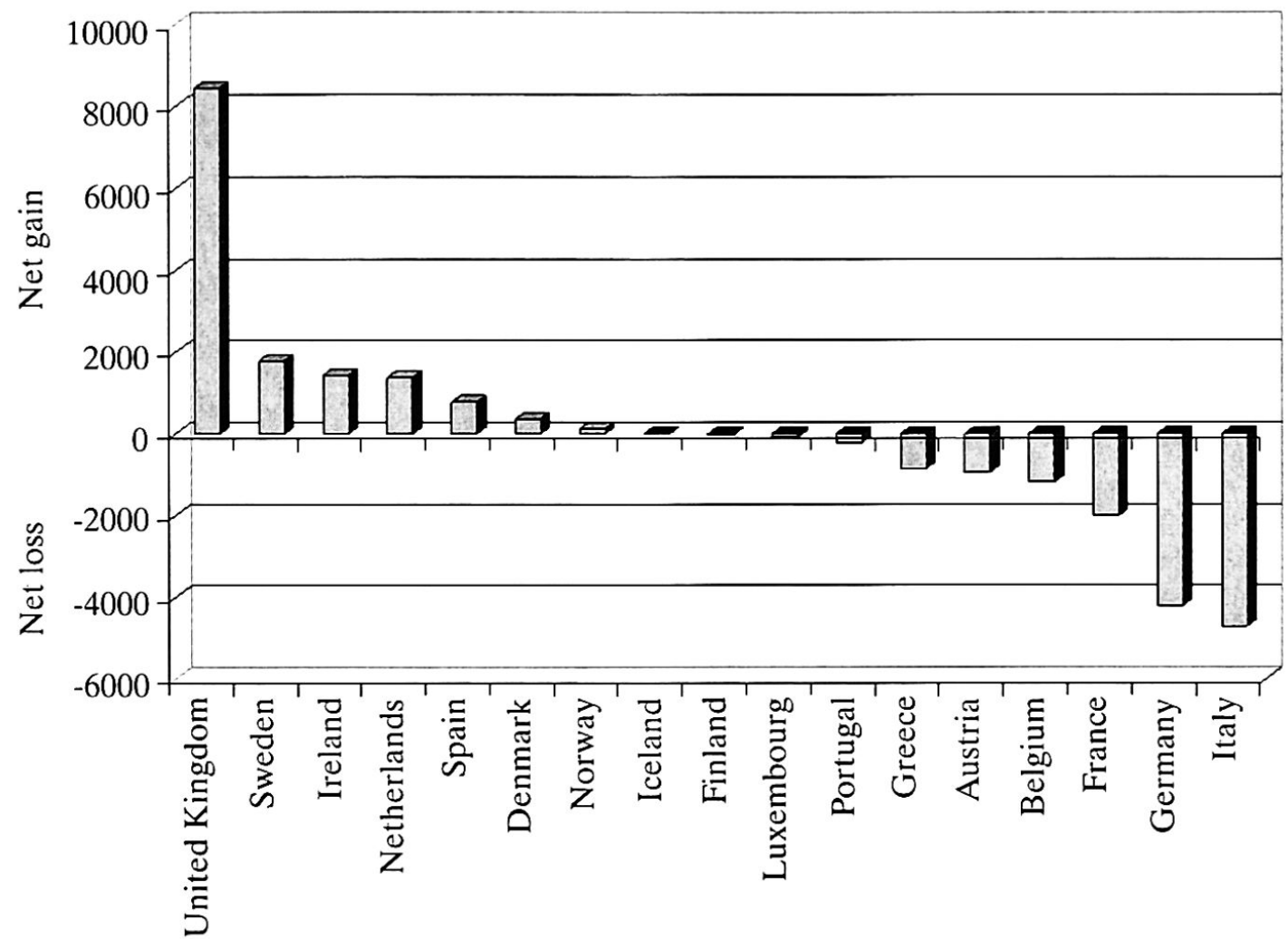

Fig. 1: Net balance of Erasmus students across the EU in 2001/2

Balance nette d'étudiants Erasmus dans l'UE, 2001/2

Erasmus-Studierende in der EU in den Jahren 2001/2

Source: Socrates-Erasmus Council for Higher Education (2003)

contextualisation of their comments. Inevitably, only a few excerpts from the interviews can be reproduced here; fuller details can be found in the final research report (KING et al. 2004b).

Some basic statistics from the questionnaire survey help to frame the context of the qualitative data which constitute the remainder of this paper. Amongst finalyear students for whom mobility was voluntary (i.e. excluding groups such as language students for whom study abroad was a prerequisite of their course), some $5.5 \%$ had engaged in international mobility. For language students the rate was $95.5 \%$ (the remainder largely exempted because of having foreign experience prior to taking up their studies). Amongst those who had been away, $54 \%$ had been on Erasmus exchanges. Whereas language students favoured Socrates-Erasmus mobility $(61 \%)$, most other students went on institutionally-organised exchanges (26\%), Erasmus $(24 \%)$ or work placements $(19 \%)$. Overall, France was the most popular destination ( $42 \%$ ), followed by Spain $(20 \%)$ and Germany $(16 \%)$. But the subset of nonlanguage students was very different, with the USA being by far the most popular destination.

\section{The meanings and experiences of international student mobility}

\subsection{The seeds of migration}

There are many ways of seeking to understand why students, like any other migrant group, decide to move. For example, our questionnaire survey asked mobile final-year students what was the «dominant» reason for their international mobility. Just under three-quarters replied that course requirements and the necessity of enhancing language skills were the key factors, but such responses beg the questions of why students registered for courses with these requirements, why the numbers studying languages at British universities have been in steep decline, and why there has been such a lack of interest in the Socrates-Erasmus mobility programme amongst students registered on other (non-language) courses.

Our questionnaire study yielded many useful findings (for a summary see KING et al. 2004a), but from the perspective of geographers seeking to understand migration, such surveys tend to encourage respondents to rationalise their actions in the specific time-space of 


\begin{tabular}{|c|c|c|}
\hline $\begin{array}{l}\text { Debbie - History and French, } 1 \\
\text { year spent in France }\end{array}$ & $\begin{array}{l}\text { Elaine - Geography, } 1 \text { year spent } \\
\text { in France }\end{array}$ & $\begin{array}{l}\text { Callum - Journalism, } 1 \\
\text { semester spent in Spain }\end{array}$ \\
\hline $\begin{array}{l}\text { «.. yeah, we always went on } \\
\text { holidays abroad with my parents } \\
\text { when we were little, to France, } \\
\text { Spain, Malta ... and we also } \\
\text { visited my uncle in the US a } \\
\text { couple of times. My parents } \\
\text { would always take us to visit } \\
\text { places there, and we heard the } \\
\text { locals speaking their own } \\
\text { languages, and saw how they } \\
\text { lived and stuff ... so, I'm sure } \\
\text { this might have had an impact } \\
\ldots \text { well, it had an impact on me, } \\
\text { certainly.» }\end{array}$ & $\begin{array}{l}\text { «I think it was clear since the } \\
\text { beginning. I had always wanted } \\
\text { to live abroad and experience a } \\
\text { different culture. Also, I had } \\
\text { studied French at school and I } \\
\text { went to France a couple of times } \\
\text { on school trips and liked it there } \\
\ldots \text { I thought that if I learned } \\
\text { French this would in a sense } \\
\text { enable me to give an interna- } \\
\text { tional edge to my career ... I'd } \\
\text { like to travel when I graduate } \\
\text { next year, and perhaps settle } \\
\text { elsewhere for a while.» }\end{array}$ & $\begin{array}{l}\text { «... I had always wanted to live } \\
\text { abroad for a while and learn } \\
\text { another language and stuff, so } \\
\text { I went to see him [the Erasmus } \\
\text { coordinator] ... in the end it } \\
\text { was quite easy because they } \\
\text { organised everything ....» }\end{array}$ \\
\hline
\end{tabular}

Tab. 1: Student reflections of the origins of their interest in international migration Réflexions d'étudiants quant aux origines de leur intérêt pour la mobilité internationale Studentische Überlegungen zu Hintergründen ihrer internationalen Mobilität

their migration movements (HALFACREE \& Boyle 1993). The in-depth interviews provided much more nuanced accounts that located the meaning of student migration within their wider life-course and mapped it relative to social values absorbed from the social discourse of family, friends and community (FINDLAY \& STOCKDALE 2003). Consider the excerpts listed in Table 1.

All three voices remarked that they had «always» wanted to live abroad. Clearly this turn of phrase is somewhat misleading since people are not born with the desire to migrate, but it points to the deeply-rooted nature of the causes promoting mobility. Many students (not all) stressed that the underlying motivation (or resistance) to migrate pre-dated their arrival at University. Some traced the longing to childhood experiences with parents (Debbie) or their upbringing in families that looked positively on international opportunities. For others their relative fixity was contingent on the immobility of their home backgrounds.

«Of course all our parents didn't get this opportunity to go abroad, .... So, for lots of my friends who are from farming backgrounds, their parents are like [saying] ... \& But why do you need to go away?) ... It's kind of that mentality as well, because they never got to" (JoANNA - Geography).

Some mobile students, such as Elaine (Table 1), attributed their mobility to the influence of teenage foreign travel with school friends. Even where school had not formally organised international travel, it was often the social milieu in which students had first discussed going or living abroad. For example, discussion of Gap Year options prior to coming to University produced a significant discourse amongst young people that established social attitudes to international mobility. The questionnaire survey also revealed that those who chose to go on a Gap Year before University were $50 \%$ more likely to re-engage with the international opportunities offered later by the Higher Education system.

Although many students had the «seed» of migration (FINDLAY \& LI 1997) planted prior to coming to University, it was the networks of mobility opened up by the education system that made the mechanics of student migration possible (Callum, Table 1). This is a point to which we will return.

To summarise, the interviews attested the socially and historically embedded nature of many students' values in shaping their intentionality with regard to student migration. Inversely students from backgrounds with greater relative "contingent fixity» (CLARKE 2004), by which we mean students from backgrounds that were less open to international experiences, were much less likely to subsequently engage in international migration.

\subsection{Perceptions of the value of student migration}

As well as pointing to the need to interpret migration as reflecting values built up over the life course, rather 


\begin{tabular}{|c|c|c|}
\hline $\begin{array}{c}\text { Barbara - Nursing student } \\
\text { Finland }\end{array}$ & Annie - first year Maths & $\begin{array}{l}\text { Gabrielle - Maths work } \\
\text { placement scheme }\end{array}$ \\
\hline $\begin{array}{l}\text { «... a different experience, a } \\
\text { different way of living ... just to } \\
\text { travel really ... once I'm } \\
\text { qualified I want to work abroad } \\
\text { so that gave me an incentive ... } \\
\text { you do open your eyes when } \\
\text { you go abroad, compared to } \\
\text { when you stay in the same place } \\
\ldots \text {. I think that our career is very, } \\
\text { very enriched in the experience } \\
\text { and everything. I've been open } \\
\text { to stimulation by lots of experi- } \\
\text { ences over there, in teaching, in } \\
\text { friendship, in everything. It's } \\
\text { made me a richer person, } \\
\text { really.» }\end{array}$ & $\begin{array}{l}\text { «I think people look at the fact } \\
\text { that you've been abroad and } \\
\text { see that you are a more well- } \\
\text { rounded person ... That you're } \\
\text { open to new ideas and what- } \\
\text { ever. Also, like if you go to a } \\
\text { very prestigious institution } \\
\text { [abroad] ... To have a curri- } \\
\text { culum vitae like that is a key } \\
\text { to any door.» }\end{array}$ & $\begin{array}{l}\text { «It's really good for a career, like } \\
\text { nearly all the application forms } \\
\text { ask what languages you can } \\
\text { speak, and all the companies now } \\
\text { are so multinational ... aren't } \\
\text { they? ... like last year I was at } \\
\text { British Aerospace working on } \\
\text { computer programmes and half } \\
\text { of them were in French ... and } \\
\text { everyone at work was learning } \\
\text { French; it was compulsory to } \\
\text { learn French.» }\end{array}$ \\
\hline
\end{tabular}

Tab. 2: Student voices discussing the meaning of their international experiences

Témoignages d'étudiants quant au sens de leur expérience internationale Aussagen von Studierenden zum Sinn ihrer internationalen Erfahrungen

than as an event set only in the immediate context of the student at the point of departure, the interviews also illustrated the instrumental value of mobility in the eyes of students. The longer-term meaning of their international experiences is evidenced in three student quotes in Table 2.

There seems support here, and in the wider range of interviews, for the view that students interpreted time abroad as potentially valuable for their future career development (Annie), for language acquisition (Gabrielle) and for personal enrichment (Barbara). These views relate to aspects of KING and RUIZ-GeLICES' (2003) typology of the benefits of student migrations, although it should be noted that students often expressed a complex intertwining of experiences. In reality, student migration seems to be driven by a diversity of intentions rooted in past experiences and also linked to a colourful tapestry of imagined future benefits.

Future labour market prospects, identified by several students we interviewed, were recognised as a social and economic benefit. Employers were perceived as equating international travel with positive attributes such as «open to new ideas» (Annie) and «open to stimulation» (Barbara). Such interpretations are clearly culturally embedded, and speak also to students' perceptions of the negative attributes associated with immobility.
The interviews revealed many shared views on the cultural geography of the United Kingdom as understood by students. Explaining why he thought so few British students sought outward mobility during their studies, Harry notes:

«I think Britain is a very insular country. We're an island and people just come to us, which is a very stupid attitude. Also, probably there's an element of reverybody speaks English, so what's the point»» (HARRY - Geography - firstyear student).

And Joanna too, commented on the restrictive mobility culture in which British students are embedded:

«... you know differences are always picked up as negative... I think there isn't an appreciation of difference ... I think there's an element of British people just not wanting to experience or look past their own culture. .... before I went away, I worked in an office with about twenty women, sort of middle-aged, and none of them could understand why I wanted to go - none of them, not one of them ... in fact they said to me swhy are you doing this?? ... I said 'because you've got to experience different things', and they were like 'why? . ...." (JoAnNA - Geography - first semester student in Canada).

Harry and Joanna's comments reveal the awareness of some students - especially those interested in interna- 
tional mobility - that their views were out of line with dominant understandings of the meaning of migration. They point to the deep-seated cultural barriers that form a much more profound deterrent to student migration than the factors elicited by our questionnaire - barriers such as the cost of living abroad, linguistic insecurity, lack of information about international opportunities, wishing to stay close to a boy/ girlfriend and the risk of prolonging their degree (KING et al. 2004a and b). These barriers were also picked up on by the interviewees, but were not interpreted as problematic in the same way as a student's cultural orientation towards mobility as developed over the life course (quotes by Debbie and Elaine). While University or Government policies might be devised to mitigate factors such as language skills, finance or information, it was less clear how «negative» parental influence or the absence of a "positive» mobility culture could be addressed in such a way as to encourage a student «to experience or look past their own culture» (Joanna).

\subsection{Mobility networks}

It would be easy to conclude from the above that a full understanding of student migration can be achieved purely from in-depth student interviews. In practice such an interpretation would be just as incomplete an interpretation of the geography of student mobility as would be an analysis resting only on questionnaire returns. Other qualitative research we carried out revealed the importance of key structural factors in shaping student mobility patterns. Here we bring in our interviews with «mobility managers». There is only space here for a few quotes to illustrate how national, regional and institutional factors structure student migration choices.

Consider the comments of an employee of an organisation seeking to promote student mobility from Northern Ireland to North America:

«The programme is to develop future managers, to develop the business and management skills of our pre-final year degree and diploma students from any discipline, to improve the core skills of all participants, to provide students with an outward-looking international experience, and to raise the economic, political and cultural awareness of Northern Ireland ... Our aim is not that these people go and see America as a land of opportunity and the place they want to make their future life ... We want them to bring it home, and that's why we take them out at undergraduate level, they must come back to do one final year of their degree programme. If that wasn't there, I think you might find some of them staying on, in large numbers. Of course, that would be contrary to our goals ..." (IAN - government-sponsored student mobility manager Northern Ireland).
These comments attest the purposive nature of the systems established to encourage student mobility. The networks through which students move are not neutral ones, but shaped and managed to achieve particular ends. Thus while students assert their agency in migrating to study or work abroad, they do so in circumstances that have been developed by others with specific goals. In Ian's terms these are not only to do with "core skills» but are also informed by issues such as political and cultural awareness, and the priority to bring the students back home for the benefit of Northern Ireland.

University staff charged to organise student exchanges also recognised that study locations were constantly under review in relation to the institution's financial, research and graduate employability targets. Thus Jean explained:

"We have, in fact, narrowed our list of contacts. Once we had a network which embraced a lot of European countries ... most of our exchanges are now with French business schools» (JEAN - Erasmus exchange coordinator).

\section{Another mobility coordinator remarked:}

\section{«... to get our students to go I have to be very careful. I mean, there's no point in me taking an offer from Kaza- khstan because nobody will go to Kazakhstan. ... Our stu- dents are very reserved.... all my students, it sounds awful, are white and British ...» (JoHN - exchange programme coordinator for an agency funding student exchanges).}

Thus mobility managers establish mobility and exchange structures often governed by the financial frameworks laid down by institutions, governments or international organisations (such as those underpinning the Socrates-Erasmus system), but these structures are in turn affected by agency (student willingness to migrate to certain destinations). So, structure affects agency which in turn affects structure in a recursive inter-linked process of the kind anticipated by structuration theory (GIDDENS 1984). This is a simple, yet powerful point - student mobility is organised by a system that is governed by mobility managers located in a higher education system, but the patterns of mobility are structured geographically not only by what those managers interpret to be appropriate educational and cultural goals (Ian's quote), but in line with what are imagined to be the desired destinations of British students (John's quote).

\section{Reflections on research praxis and policy dimensions of student migration}

We started by arguing that international student migration is neglected relative to the attention given to other forms of mobility. Elsewhere the authors have used quantitative evidence to extend understanding of the 
determinants of student mobility (KING et al. 2004b). Such work has value both to geographers, and also for policy-makers eager to promote greater student migration by manipulating financial and educational parameters. Our purpose here, however, has been to demonstrate that, without understanding something of the nature of mobility cultures, many dimensions of international student mobility will remain inaccessible both to academics and policy-makers. And to achieve this qualitative methods informed by structuration theory have proved invaluable.

From the perspective of researching the geography of international migration, this paper has provided ample evidence that the drivers of student mobility are different from those influencing labour migration or housing market moves. Our perspective has not only recognised the social embeddedness of migration processes but has also illustrated the interweaving roles of structure and agency in shaping migration patterns. Those who structure international student mobility networks (e.g. politicians promoting pan-European ideals or university deans pursuing the internationalisation of their faculties through targeted student exchange programmes designed to maximise research benefits to staff) define geographies of mobility that are conditioned by very different imperatives from those that structure, for example, international labour migration. Furthermore, the structuration of student mobility occurs within a short time-frame that is itself nested within the transitory student experience of higher education. All these factors contribute to the distinctiveness of this form of mobility and to the value of pursuing further geographical research in this area. We therefore conclude that geographers have much to gain from mapping the meanings as well as the spatiality of student migration.

This is not to say that the methods we have used are unproblematic. We are reflexively self-critical of the way in which our research agenda has inevitably influenced our selection of voices in the preparation of this paper. In re-reading the many quotations from our interviews, we have asked ourselves to what extent we have unjustifiably reified some concepts (e.g. seeds of migration, the openness that comes from student mobility) at the expense of others (PotTer et al. 1990). And we are well aware of the dangers of fossilising students' interpretations of the meaning of their experiences by recording them at only one point in time. We recognise that in practice individuals draw differently on their migration biographies as their contexts change over the life course (FInDLAY \& Li 1997). What we would stress is that, in our judgement, while bearing these critical reflections in mind, the value of the methods we have used in our understanding of student mobility not only far outweighed the problems, but they open up insights which otherwise would not have been achieved.
The policy implications of our findings are several. We can dwell on only three key points here. First, the research highlights the challenge to policy-makers wishing to make a rapid change in the scale of student migration. While better financing of mobility schemes and wider awareness of the benefits associated with international opportunities may have some effect on the number of UK students participating in exchanges, the student voices signal a much longer-term dimension to migration, necessitating implementation of strategies targeted to prepare school pupils for the possibility of international mobility during higher education. This proposal is given voice by Barbara:

«... it's about going into the schools, and starting there to promote it ... get them young, I think. Because then their mentality is different» (BARBARA - Nursing - Finland).

As she notes, this is not just a life-course issue, requiring long-term perspectives in planting potential seeds of migration, but it is also a mentality issue. Is it possible that the evolving social discourse in the United Kingdom increasingly militates against international mobility?

Second, many of the student voices signalled the powerful role of culture (in the United Kingdom's case perhaps a «culture of immobility») in governing attitudes to movement. Migration research that examines only an individual's behavioural decision-making process and ignores cultural elements outside this «box», will fail to address fundamental policy questions such as why a society should embrace (or resist) the potential global interactions offered by international student exchanges. Identifying such cultural drivers is improbable in quantitative surveys examining the personal characteristics or ecological correlates of migrant propensities. Our qualitative analysis suggests that students' intentions are socially embedded and cannot be meaningfully separated from wider discourses on the meaning of international opportunities. While these seem to support student mobility in countries like Germany, Spain, Italy and France (MurPhy-LeJeune 2003), this is not the case in the United Kingdom. To change a prevailing mobility culture is a much greater challenge than most regimes at state or institutional level wish to tackle, yet it is at this level that the most fundamental parameters of student mobility are set.

A third policy issue worth highlighting is the emphasis placed by many students on the value of working (as opposed to studying) in another country (quotes by Barabara and Gabrielle). This valuable insight leads to a questioning of the balance within the current British structure of student mobility opportunities (and indeed the thrust of the Socrates-Erasmus programme) in favour of study exchanges as opposed to work placements. 


\section{Conclusions}

This paper has explored the under-researched topic of student international migration. It has done so by listening to student voices in an attempt to extend geographical understanding beyond what is knowable from secondary data and structured questionnaire surveys. Students, like other potential migrants, live their lives amongst other people, and so their biographies are not only socially embedded, but the choices they make are socially referenced and involve an understanding over the life-course of social norms and cultural practices (ERBEN 1993).

We have argued that student mobility cannot be understood solely in terms of the conscious values and intentions of students as expressed in questionnaire surveys. Qualitative research also reveals the interaction of student agency and structural influences operating at institutional, regional and national levels. For this reason we have advocated, and partially illustrated, a structurationist perspective to the study of student mobility. This involves analysing the relations between structure and agency in a way that interprets the properties of social systems (in this case the social contexts and structures of international student migration networks) as being «both the medium and the outcome of the practices that constitute those systems» (Giddens 1979: 69).

\section{Acknowledgement}

The research was financed by the following: Higher Education Funding Council for England, Scottish Higher Education Funding Council, Higher Education Funding Council for Wales, Department for Education and Skills, British Council, British Universities Transatlantic Exchange Association, UK Department for Employment and Learning.

\section{References}

Altbach, P.G. \& U. Teichler (2001): Internationalisation and exchanges in a globalized university. - In: Journal of studies in international education 5, 1:5-25.

BECK, U. \& E. BECK-GERNSHEIM (2002): Individualisation. - London: Sage.

BRUSH, T. \& A. BARTY (1998): Internationalising British higher education: students and institutions. - In: Scotr, P. (ed.): The globalisation of higher education. Buckingham: Oxford University Press and Society for Research into Higher Education: 18-31.

CASTLES, S. \& M.J. MiLLER (1998): The age of migration: international population movements in the modern world. - London: Macmillan.

N. Clarke (2004): Mobility, fixity, agency: Australia's working holiday programme population. - In: Population, space and place 10:411-420.
Commission of the European Communities (2000): Survey into the socio-economic background of Erasmus students. - Brussels: Directorate General for Education and Culture.

ERBEN, M. (1993): The problem of other lives. - In: Sociology 27: 15-25.

FAVELL,A. (2004): Eurostars and eurocities, free moving professionals and the promise of European integration. - In: European studies newsletter 33, 2/4: 1-11.

Findlay, A.M. (2002): From brain exchange to brain gain: policy implications for the United Kingdom of recent trends in skilled migration from developing countries. - = International migration papers 43 , Geneva: International Labour Office.

FindLAY, A.M. \& F.L.N. Li (1997): An auto-biographical approach to studying migration. - In: Area 29:34-44.

Findlay, A.M. \& F.L.N. Li (1999): Methodological issues in researching migration. - In: The professional geographer 51: 50-59.

Findlay, A.M. \& A. Stockdale (2003): The temporal and social embeddedeness of migration. - In: Geographical research forum 23: 4-29.

GIDDENS, A. (1979): Central problems in social theory. - London: Macmillan Press.

Giddens, A. (1984): The constitution of society. - Cambridge: Polity Press.

Halfacree, K. \& P. Boyle (1993): The challenge facing migration research. - In: Progress in human geography 17, 3: 333-348.

Higher Education Statistics Agency (HESA) (2004): Students in higher education institutions 2002-3. Cheltenham: HESA

KING, R. (2003): International student migration in Europe and the institutionalization of identity as «young Europeans».- In:DOOMERNIK, J. \& H. KNIPPENBERG (eds): Migration and immigrants: between policy and reality. Amsterdam: Aksant Academic Publishers: 155-179.

King, R. \& E. RuIZ-Gelices (2003): International student migration and the European «year abroad»: effects on European identity and subsequent migration behaviour. - In: International journal of population geography 9, 3:229-252.

King, R., Findlay, A.M., Stam, A. \& E. Ruiz-Gelices (2004a): The UK's changing position in the international exchange of students. - In: World views 16: 5-8. King, R., Findlay, A.M., Ruiz-Gelices, E. \& A. Stam (2004b): International student mobility: final report. = HEFCE issues paper 30, London: Higher Education Funding Council for England (HEFCE).

King, R., Warnes, A. \& A.M. Williams (1998): International retirement migration. - In: International journal of population geography 4, 2: 91-112.

KuPTSCH, C. (2005): Students and talent flow. - Paper presented at a conference on «Competing for Global Talent», Singapore Technical University, January 13-14, 2005.

KwIEck, M. (2001): Globalization and higher education. - In: Higher education in Europe 26: 27-38. 
LANZendorf, U. \& U. Teichler (2002): Statistics on student mobility within the EU. - Final report to the European Parliament Directorate General for Research (Study IV/2001/13/01).

MurPhy-LejEunE, E. (2003): Student mobility and narrative in Europe: The new strangers. - London: Routledge. Potter, J., Wetherell, M., Gill, R. \& D. Edwards (1990): Discourse: noun, verb and social practice? - In: Philosophical psychology 3: 189-204.

Ruiz-Gelices, E., King, R. \& A.M. Findlay (2003): International student mobility study: annotated bibliography. - Research working paper, Centre for Migration, University of Sussex.

SCHNITZER, K. \& M. ZEMPEL-Gino (2002): Euro student: social and economic conditions of student life in Europe 2000. - Hannover: Hochschul-Informations-System.

SKELDON, R. (1997): Migration and development: a global perspective. - London: Longman.

Socrates-Erasmus Council for Higher Education (2003): Erasmus student mobility 2001. - Paper 7, annex. SOPEMI (2001): Trends in international migration. Paris: OECD.

Teichler, U. \& V. Jahr (2001): Mobility during the course of study and after. - In: European journal of education 36, 4: 443-458.

Teichler, U. \& F. MaIworm (1997): The Erasmus experience. - Luxembourg: Office for Official Publications of the European Commission.

West, A. et al. (2001): Higher education admissions and student mobility within the EU - ADMIT. - Final report of the Targeted Socio-Economic Research Programme, London: London School of Economics.

\section{Summary: International opportunities: searching for the meaning of student migration}

This paper explores aspects of the geography of international student migration. By listening to the voices of British students we make a methodological contribution in terms of extending understanding of the intentions and values of student migrants as developed over their life course. On the one hand, students stressed the social and cultural embeddedness of their actions, while on the other hand interviews with university staff and mobility managers pointed to the existence of other social structures that shape the networks of mobility that are available to students. Policy makers seeking to re-shape the geography of international student mobility need to address the deeper socio-cultural forces that selectively inhibit movement although European integration processes have long paved the way for international living and work experience.

Résumé: Options internationales de carrière: les motivations des migrations estudiantines

La présente contribution aborde différentes facettes d'un mouvement peu étudié, la migration internatio- nale estudiantine. En donnant la parole à des étudiants britanniques, l'enquête menée cherche à élargir la connaissance des motivations et échelles de valeurs développées par les étudiants migrants au cours de leur trajectoire. Les étudiants ont démontré que leurs actions s'inscrivent dans leurs valeurs sociales et culturelles. Quant aux interviews conduites auprès d'enseignants et co-ordinateurs de mobilité, elles ont permis de relever d'autres structures sociales qui influencent le comportement des étudiants. Les personnalités politiques, qui entendent promouvoir l'expérience internationale de leurs élites formatrices en matière d'études et professionnelle, doivent prendre notamment en considération les influences socio-culturelles qui réduisent la mobilité, des influences qui persistent encore, en dépit du fait que les processus européens d'intégration ne cessent de faciliter les échanges internationaux.

\section{Zusammenfassung: Internationale Karriereoptionen - zu den Hintergründen studentischer Migration}

Dieser Artikel setzt sich mit verschiedenen Gesichtspunkten der internationalen Studierendenmigration, einer noch wenig untersuchten Bewegung, auseinander. Es soll ein methodischer Beitrag dazu geleistet werden, die Erwartungen und Wertvorstellungen britischer Studierender herauszuarbeiten, wie sie sich im Laufe ihres Lebens entwickeln. Die Studierenden zeigen einerseits, dass ihr Verhalten ihren sozialen und kulturellen Kontext widerspiegelt. Andererseits ergeben Interviews mit Dozierenden und Austausch-Koordinatoren an Universitäten, dass andere soziale Strukturen und Einflüsse das Studierenden-Verhalten bestimmen. Politiker, welche die internationale Studien- und Arbeitserfahrung ihrer Bildungselite fördern wollen, müssen gerade die soziokulturellen Einflüsse, welche die Mobilität reduzieren, berücksichtigen, Einflüsse, die noch bestehen, obwohl europäische Integrationsprozesse den internationalen Austausch laufend erleichtern.

Prof. Dr. Allan M. Findlay, Alexandra Stam, Department of Geography, University of Dundee, Dundee, DD1 4HN, United Kingdom.

e-mail: a.m.findlay@dundee.ac.uk

e-mail:a.stam@dundee.ac.uk

Prof. Dr. Russell King, Enric Ruiz-Gelices, Sussex Centre for Migration Research, University of Sussex, Brighton, BN1 9SJ, United Kingdom.

e-mail: R. King@sussex.ac.uk

e-mail: e-ruiz-gelices@sussex.ac.uk

\section{Manuskripteingang/received/manuscrit entré le} 12.4.2005

Annahme zum Druck/accepted for publication/accepté pour l'impression: 25.8 .2005 